\title{
EVALUATION OF THE "ENZYMMIX F" PRODUCT AS AN ADDITIVE FOR BROILERS REARED IN AN ANTIBIOTIC-FREE SYSTEM
}

\author{
Dayana Cristina de Oliveira Pereira ${ }^{1}$, Gustavo do Valle Pereira ${ }^{1}$, Luiz Carlos Demattê Filho ${ }^{1}$, Jorge \\ Konrado Xavier de $\mathrm{Melo}^{2}$
}

\begin{abstract}
This experiment was undertaken to compare the effects of using the Enzymmix F product with a Brazilian enzyme blend in diets with different nutritional levels. A total of 1,080 male broiler chicks were distributed into a randomized-block design with a $3 \times 2$ factorial arrangement consisting of three enzyme complexes (Enzyme Blend, Enzymmix F, and the combination of both) and two nutritional levels (regular and reduced). We evaluated the birds' performance in the periods of 1 to 21 and 1 to 42 days of age. The yields of carcass and cuts and intestinal integrity were evaluated at 45 days of age. During the analyzed periods, no significant difference was observed for the performance parameters considering the "enzyme" factor. However, the reduction in the nutritional level of the diet resulted in inferior performance in both periods. There was no statistical difference for the yields (\%) of carcass and cuts. Enzymmix F provided the greatest villus height in the jejunum segment. The use of the Enzyme Blend in the nutritionally reduced diet led to a lower crypt depth. In conclusion, Enzymmix F increased the weight of wings (g) and the villus height in the jejunum.
\end{abstract}

Keywords: enzymes, Gallus gallus, intestinal integrity, nutrition.

\section{AVALIAÇÃO DO PRODUTO ENZIMMIX F COMO UM ADITIVO PARA A PRODUÇÃO DE FRANGOS DE CORTE EM SISTEMA LIVRE DE ANTIBIÓTICO}

\begin{abstract}
RESUMO - O experimento foi realizado para comparar o efeito do produto Enzymmix F ao de um complexo enzimático brasileiro, utilizando rações com diferentes níveis nutricionais. Um total de 1.080 pintos de corte machos (Cobb MX) foram distribuídos em um delineamento em blocos casualizados utilizando o esquema fatorial 3 x 2 três complexos enzimáticos (Blend enzimático, Enzymmix F e a combinação de ambos) e dois níveis nutricionais (normal e reduzido). Foi avaliado o desempenho das aves, nos períodos de 1 a 21 e 1 a 42 dias de idade. O rendimento de carcaça e cortes e a integridade intestinal foram avaliados aos 45 dias de idade das aves. Durante os períodos analisados não foram observadas diferença significativa nos parâmetros de desempenho considerando o fator "enzima". No entanto a redução no nível nutricional da ração resultou em desempenho inferior nos dois períodos. Não houve diferença estatística no rendimento (\%) de carcaça e cortes. O Uso do Enzymmix F proporcionou maior altura de vilo no segmento do jejuno. Houve interação entre os fatores estudados no que se refere a profundidade de cripta. Conclui-se que a utilização do Enzymmix F aumentou o peso de asa $(\mathrm{g})$ e proporcionou maior altura dos vilos no jejuno.
\end{abstract}

Palavras chave: enzimas, Gallus gallus, integridade intestinal, nutrição.

\footnotetext{
${ }^{1}$ Researchers at the Korin Agricultura e Meio Ambiente - Mokiti Okada Research Center, (dayana.pereira@korinagricultura.com.br)

${ }^{2}$ Korin Agropecuária Ltda
} 


\section{INTRODUCTION}

The expansion of poultry farming in the last decades has driven the search for excellence in this sector. According to Vargas et al. (2017), the nutrition area has stood out for discovering numerous alternatives to increase production based on the optimization of the use of dietary nutrients and reduction of feed costs. These functions are commonly attributed to exogenous enzymes, which play an even more important role in alternative broiler production systems such as the antibiotic-free system. As stated by Thorpe and Beal (2001), the use of exogenous enzymes offsets the reduction in animal performance caused by the restricted use of antibiotics in the diet. Poultry are the species that most benefit from the use of exogenous enzymes, which is mainly because of their very short digestive system that does not allow for enough digestion time (Mavromichalis, 2012).

According to Barbosa et al. (2014), enzymes act as biological catalysts, and their adoption enables a greater utilization of diet nutrients such as phosphorus, calcium, amino acids, and energy, resulting in better production efficiency, greater economy in feeding, and benefits to the environment. These last two benefits partly stem from the possibility of working with less dense diets, considering that enzyme supplementation elevates the nutritional value of ingredients and improves the degree of precision in their formulation (Ravindran, 2013).

Within this perspective and considering the nutritional relevance of including exogenous enzymes in poultry diets, the present study was conducted to compare the effect of the Enzymmix F product with that of a Brazilian enzyme complex, in diets with different nutritional levels, on the performance parameters, yields of carcass and cuts, and intestinal integrity of broilers.

\section{MATERIALAND METHODS}

This study was carried out according to the ethical principles in animal experimentation and was approved by the local Research Ethics Committee.

The experiment started in July 2017 and took place on the Serra Dourada farm, located in the municipality of Ipeúna - SP, Brazil. The study involved 1,080 oneday-old Cobb MX male chicks with a live weight of $47.83 \pm 3.07 \mathrm{~g}$ vaccinated against Marek’s disease, fowlpox, infectious bursal disease, and coccidiosis Birds were housed in thirty-six $1.0 \times 2.5 \mathrm{~m}\left(2.5 \mathrm{~m}^{2}\right)$ cages at the rate of $30 \mathrm{birds} / \mathrm{cage}$, corresponding to a density of $12 \mathrm{birds} / \mathrm{m}^{2}$. Each cage had an individual water- and feed-supply system; these were available to the animals ad libitum. Temperature $\left({ }^{\circ} \mathrm{C}\right)$ and ventilation were controlled by curtain management and activation of fans and a misting system whenever necessary. Two data loggers (Hobo $\left.{ }^{\circ} \mathrm{H} 08-00 \mathrm{X}-02\right)$ were installed in the shed to measure the temperature and humidity in the facility. The chicken litter (6-mm thickness) used in the experiment was made of powdered pine bark.

The lighting program adopted was that recommended by Humane Farm Animal Care (2009), considering that the birds were kept in a certified production unit regarding the animal welfare norms. This unit was also certified for not using antibiotics, chemotherapeutics, or animal ingredients in the diets. Following these guidelines, the diets were formulated based on corn and soybean, according to the composition of feedstuffs presented by Rostagno et al. (2011). The feeding program was divided into five phases: starter (1-7 days), developer (8-21 days), grower 1 (22-28 days), grower 2 (29-35 days), and finisher (36-45 days).

Three enzyme complexes (Enzyme Blend, Enzymmix $\mathrm{F}$, and the combination of both) and two dietary nutritional levels (regular and reduced) were evaluated. The analyzed treatments are described in Table 1. The experiment was analyzed as a $3 \times 2$ factorial arrangement consisting of three enzyme complexes and two dietary nutritional levels (Tables 2 and 3), constituting six treatments (Table 1) that were distributed into randomized blocks with six replicates of 30 birds each.

It should be noted that a control treatment (without enzyme) was not established due to previous knowledge of the positive effect of the Brazilian enzyme complex on broiler performance. Thus, this product was used as the control in this research.

The Enzyme Blend is a Brazilian commercial product that contains two active enzymes [glucanase (860 UV/ $\mathrm{kg})$ and xylanase $(1,250 \mathrm{UV} / \mathrm{kg})]$ produced by a single non-genetically modified fungus (Talaromyces versatilis).

Enzymmix $F$ is a European enzyme complex registered for use in animal production that contains four mediumsized enzymes: pepsin A (65-90 U/mL), trypsin (80-100 $\mathrm{U} / \mathrm{mL})$, amylase $(60-90 \mathrm{U} / \mathrm{mL})$, and triacylglycerol lipase 
Table 1 - Description of treatments

\begin{tabular}{ccc}
\hline Treatment & Enzyme used & 1Nutritional level of the diet \\
\hline T 1 & Enzymmix F & Regular \\
T 2 & Enzymmix F & Reduced \\
T 3 & Enzyme Blend & Regular \\
T 4 & Enzyme Blend & Reduced \\
T 5 & Enzymmix F + Enzyme Blend \\
T 6 & Enzymmix F + Enzyme Blend & Regular \\
\hline
\end{tabular}

${ }^{1}$ Reduction: $100 \mathrm{kcal} \mathrm{ME} / \mathrm{kg}$ apparent ME, 3\% limiting AA, and 2 units of crude protein. Adapted from Meneghetti (2013).

Table 2 - Composition of the diets with regular nutritional levels

\begin{tabular}{|c|c|c|c|c|c|}
\hline Ingredient/phase & Starter & Developer & Grower 1 & Grower 2 & Finisher \\
\hline Bulk corn for feed & 48.32 & 51.07 & 52.71 & 54.83 & 57.21 \\
\hline Common soybean meal & 24.10 & 19.70 & 10.70 & 6.20 & 2.30 \\
\hline Deactivated full-fat soybean & 23.00 & 24.70 & 32.10 & 34.50 & 36.20 \\
\hline Ground calcitic limestone & 1.17 & 1.17 & 1.14 & 1.12 & 1.12 \\
\hline Dicalcium phosphate & 1.87 & 1.84 & 1.86 & 1.88 & 1.90 \\
\hline Common salt & 0.44 & 0.41 & 0.39 & 0.37 & 0.37 \\
\hline DL-methionine & - & - & - & - & - \\
\hline L-lysine HCL & - & - & - & - & - \\
\hline L-threonine & - & - & - & - & - \\
\hline Sodium bicarbonate & 0.10 & 0.10 & 0.10 & 0.10 & 0.10 \\
\hline Premix (starter and development phases) & 1.00 & 1.00 & -- & - & - \\
\hline Premix (grower phases) & - & - & 1.00 & 1.00 & - \\
\hline Premix (finisher phase) & -- & -- & -- & - & 0.80 \\
\hline TOTAL & 100.00 & 100.00 & 100.00 & 100.000 & 100.00 \\
\hline \multicolumn{6}{|c|}{ Nutritional level } \\
\hline Metabolizable energy (kcal/kg) & $2,950.00$ & $3,000.00$ & $3,100.00$ & $3,150.00$ & $3,200.00$ \\
\hline Crude protein $(\%)$ & 22.50 & 21.35 & 20.00 & 19.00 & 18.00 \\
\hline Dig. lysine $(\%)$ & 1.32 & 1.25 & 1.17 & 1.11 & 1.02 \\
\hline Dig. methionine (\%) & 0.69 & 0.68 & 0.62 & 0.61 & 0.51 \\
\hline Dig. threonine $(\%)$ & 0.85 & 0.81 & 0.77 & 0.73 & 0.67 \\
\hline
\end{tabular}

${ }^{1}$ Guarantees per kg of the product (min): vitamin A 12,000,000 IU; vitamin D3 3,000,000 IU; vitamin E $30.00 \mathrm{IU}$; vitamin K3 $4.37 \mathrm{mg}$; vitamin B1 $2.88 \mathrm{mg}$; vitamin B2 $7.20 \mathrm{mg}$; vitamin B6 $3.84 \mathrm{mg}$; vitamin B12 $18.80 \mathrm{mcg}$; choline $0.44 \mathrm{~g}$; niacin $40 \mathrm{mg}$; pantothenic acid $15.60 \mathrm{~g}$; folic acid $2 \mathrm{mg}$; iron $72.00 \mathrm{mg}$; manganese $144.00 \mathrm{mg}$; zinc $108.00 \mathrm{mg}$; copper $14.40 \mathrm{mg}$; iodine $1.80 \mathrm{mg}$; and selenium $0.36 \mathrm{mg}$.

${ }^{2}$ Guarantees per kg of the product (min): vitamin A 10,000,000 IU; vitamin D3 2,500,000 IU; vitamin E $37.00 \mathrm{IU}$; vitamin K3 $3.64 \mathrm{mg}$; vitamin B1 $2.40 \mathrm{mg}$; vitamin B2 $6.00 \mathrm{mg}$; vitamin B6 $3.20 \mathrm{mg}$; vitamin B12 $15.60 \mathrm{mcg}$; choline $0.39 \mathrm{~g}$; niacin $32.00 \mathrm{mg}$; pantothenic acid $14.00 \mathrm{~g}$; folic acid $1.60 \mathrm{mg}$; iron $60.00 \mathrm{mg}$; manganese $120.00 \mathrm{mg}$; zinc $90.00 \mathrm{mg}$; copper $12.00 \mathrm{mg}$; iodine $1.50 \mathrm{mg}$; and selenium $0.36 \mathrm{mg}$.

${ }^{3}$ Guarantees per $\mathrm{kg}$ of the product (min): vitamin A 10,000,000 IU; vitamin D3 2,450,000 IU; vitamin E 20.00 IU; vitamin K3 $3.64 \mathrm{mg}$; vitamin B1 $2.40 \mathrm{mg}$; vitamin B2 $6.00 \mathrm{mg}$; vitamin B6 $3.20 \mathrm{mg}$; vitamin B12 $15.60 \mathrm{mcg}$; choline 0.36 g; niacin $32.00 \mathrm{mg}$; pantothenic acid $14.00 \mathrm{~g}$; folic acid $1.60 \mathrm{mg}$; iron $60.00 \mathrm{mg}$; manganese $120.00 \mathrm{mg}$; zinc $90.00 \mathrm{mg}$; copper $12.00 \mathrm{mg}$; iodine $1.50 \mathrm{mg}$; and selenium $0.36 \mathrm{mg}$.

(60-90 U/mL). This product was obtained from an invertebrate (Eisenia foetida) culture, from which the enzymes were extracted.

The inclusion levels and forms of administration of the products complied with the recommendations of the manufacturers. Enzymmix F was provided in the water available in the drinkers at the rate of $1 \mathrm{~mL}$ of product for every $1,000 \mathrm{~mL}$ of water. The Enzyme Blend was provided as an additional supplement in the diet, at the rate of $0.050 \mathrm{~kg} / \mathrm{t}$.

Production-performance parameters were evaluated in the periods of 1 to 21 and 1 to 42 days of age. Body weight (BW) gain was calculated as the difference between the final and initial weights for each investigated period. 
Table 3 - Composition of the experimental diets with reduced nutritional levels

\begin{tabular}{|c|c|c|c|c|c|}
\hline Ingredient/phase & Starter & Developer & Grower 1 & Grower 2 & Finisher \\
\hline Bulk corn for feed & 59.39 & 62.03 & 63.74 & 65.77 & 68.24 \\
\hline Common soybean meal & 33.60 & 29.30 & 20.20 & 15.80 & 11.90 \\
\hline Deactivated full-fat soybean & 2.20 & 3.90 & 11.30 & 13.70 & 15.30 \\
\hline Ground calcitic limestone & 1.19 & 1.19 & 1.16 & 1.14 & 1.14 \\
\hline Dicalcium phosphate & 1.93 & 1.90 & 1.93 & 1.95 & 1.97 \\
\hline Common salt & 0.43 & 0.41 & 0.387 & 0.36 & 0.36 \\
\hline DL- methionine & 0.006 & 0.006 & 0.006 & 0.003 & 0.011 \\
\hline L-lysine HCL & 0.112 & 0.120 & 0.121 & 0.130 & 0.127 \\
\hline L-threonine & 0.042 & 0.043 & 0.051 & 0.046 & 0.052 \\
\hline Sodium bicarbonate & 0.10 & 0.10 & 0.10 & 0.10 & 0.10 \\
\hline${ }^{1}$ Premix (starter and development phases) & 1.00 & 1.00 & - & - & - \\
\hline${ }^{2}$ Premix (grower phases) & - & - & 1.00 & 1.00 & - \\
\hline${ }^{3}$ Premix (finisher phase) & - & - & - & - & 0.80 \\
\hline TOTAL & 100.00 & 100.00 & 100.00 & 100.000 & 100.00 \\
\hline \multicolumn{6}{|c|}{ Nutritional level } \\
\hline Crude protein $(\%)$ & 20.50 & 19.35 & 18.00 & 17.00 & 16.00 \\
\hline Dig. lysine $(\%)$ & 1.28 & 1.21 & 1.13 & 1.08 & 0.99 \\
\hline Dig. methionine (\%) & 0.67 & 0.66 & 0.62 & 0.61 & 0.50 \\
\hline Dig. threonine $(\%)$ & 0.82 & 0.79 & 0.75 & 0.71 & 0.65 \\
\hline
\end{tabular}

${ }^{1}$ Guarantees per kg of the product (min): vitamin A 12,000,000 IU; vitamin D3 3,000,000 IU; vitamin E 30.00 IU; vitamin K3 4.37 mg; vitamin B1 $2.88 \mathrm{mg}$; vitamin B2 $7.20 \mathrm{mg}$; vitamin B6 $3.84 \mathrm{mg}$; vitamin B12 $18.80 \mathrm{mcg}$; choline $0.44 \mathrm{~g}$; niacin $40 \mathrm{mg}$; pantothenic acid $15.60 \mathrm{~g}$; folic acid $2 \mathrm{mg}$; iron $72.00 \mathrm{mg}$; manganese $144.00 \mathrm{mg}$; zinc $108.00 \mathrm{mg}$; copper $14.40 \mathrm{mg}$; iodine $1.80 \mathrm{mg}$; and selenium $0.36 \mathrm{mg}$.

${ }^{2}$ Guarantees per kg of the product (min): vitamin A 10,000,000 IU; vitamin D3 2,500,000 IU; vitamin E $37.00 \mathrm{IU}$; vitamin K3 $3.64 \mathrm{mg}$; vitamin B1 $2.40 \mathrm{mg}$; vitamin B2 $6.00 \mathrm{mg}$; vitamin B6 $3.20 \mathrm{mg}$; vitamin B12 $15.60 \mathrm{mcg}$; choline $0.39 \mathrm{~g}$; niacin $32.00 \mathrm{mg}$; pantothenic acid $14.00 \mathrm{~g}$; folic acid $1.60 \mathrm{mg}$; iron $60.00 \mathrm{mg}$; manganese $120.00 \mathrm{mg}$; zinc $90.00 \mathrm{mg}$; copper $12.00 \mathrm{mg}$; iodine $1.50 \mathrm{mg}$; and selenium $0.36 \mathrm{mg}$.

${ }^{3}$ Guarantees per kg of the product (min): vitamin A 10,000,000 IU; vitamin D3 2,450,000 IU; vitamin E $20.00 \mathrm{IU}$; vitamin K3 $3.64 \mathrm{mg}$; vitamin B1 $2.40 \mathrm{mg}$; vitamin B2 $6.00 \mathrm{mg}$; vitamin B6 $3.20 \mathrm{mg}$; vitamin B12 $15.60 \mathrm{mcg}$; choline $0.36 \mathrm{~g}$; niacin $32.00 \mathrm{mg}$; pantothenic acid $14.00 \mathrm{~g}$; folic acid $1.60 \mathrm{mg}$; iron $60.00 \mathrm{mg}$; manganese $120.00 \mathrm{mg}$; zinc $90.00 \mathrm{mg}$; copper $12.00 \mathrm{mg}$; iodine $1.50 \mathrm{mg}$; and selenium $0.36 \mathrm{mg}$.

Birds were weighed per pen (experimental unit). Feed intake was calculated as the difference between the total feed supplied and orts remaining at the end of each feeding phase. Feed conversion ratio (FCR) was calculated as total feed intake divided by weight gain, corrected for mortality (MO), as proposed by Sakomura and Rostagno (2007). Mortality was recorded daily. The production efficiency index was calculated using the following equation: $\mathrm{PEI}=\left(\left(\mathrm{BW}^{*}(100 \mathrm{MO})\right) /\right.$ $($ Age*FCR))*100.

At 45 days, when the slaughter of free-antibiotic chickens on the farm under study occurs, six birds $10 \%$ heavier or lighter than the average weight of the unit were slaughtered per treatment for an assessment of intestinal integrity, whole-carcass yield (\%) and absolute weight $(\mathrm{g})$ and yield (\%) of cuts. The carcass yield was determined as the ratio between the weight of the eviscerated carcass and the live-bird weight, after an 8-h feed-deprivation period. The yields of cuts (breast, drumstick + thigh, and wing) were also determined; these were weighed and their yields were calculated relative to the eviscerated-carcass weight.

The studied variables' data were subjected to a Shapiro Wilk normality test and analysis of variance. Means were compared by Tukey's test at the 5\% significance level.

\section{RESULTS AND DISCUSSION}

Mean values for maximum, average, and minimum temperature and humidity recorded during the experimental period are exhibited in Figure 1.

No significant difference was observed for the performance parameters considering the "enzyme" factor (Tables 4 and 5) in the periods of 1 to 21 and 1 to 42 days of age of the birds. However, the reduction of 

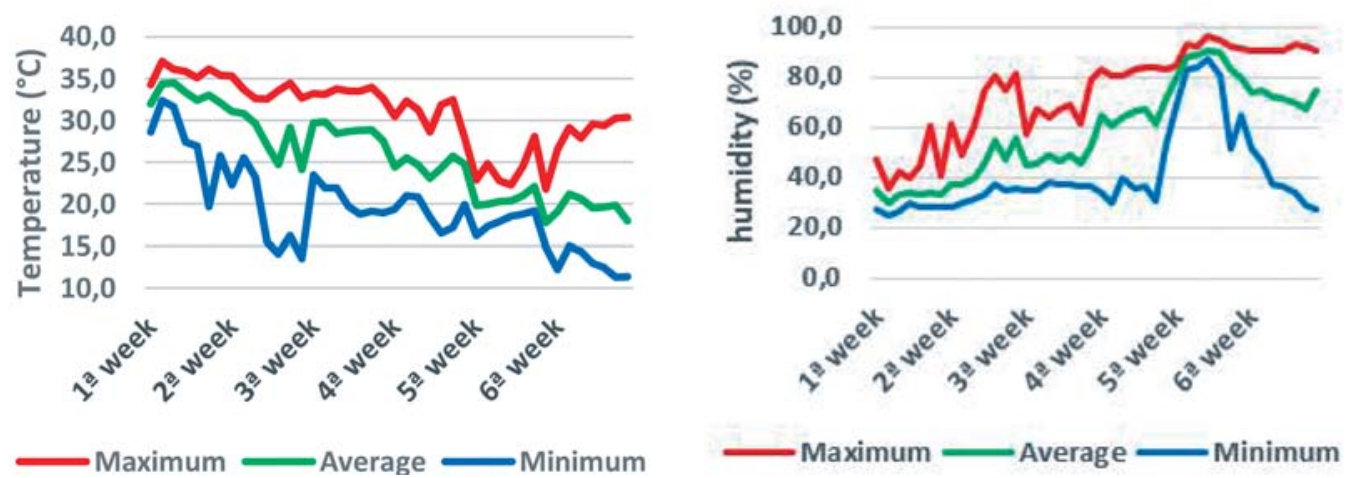

Figure 1 - Temperature and humidity during the experimental period.

Table 4 - Effect of the "enzyme" and "nutritional level" factors on performance variables in the period from 1 to 21 days of age

\begin{tabular}{|c|c|c|c|c|c|c|}
\hline \multirow{2}{*}{ Factor } & & \multicolumn{5}{|c|}{ Performance variable } \\
\hline & & DWG (g) & Weight (g) & Intake $(\mathrm{g})$ & FCR & Mortality (\%) \\
\hline \multirow[t]{3}{*}{ Enzyme (E) } & Enzymmix F & $43.38 \mathrm{~ns}$ & $959.04 \mathrm{~ns}$ & $1305.68 \mathrm{~ns}$ & $1.43 \mathrm{~ns}$ & $1.94 \mathrm{~ns}$ \\
\hline & Enzyme Blend & $42.12 \mathrm{~ns}$ & $932.26 \mathrm{~ns}$ & $1292.59 \mathrm{~ns}$ & $1.45 \mathrm{~ns}$ & $3.06 \mathrm{~ns}$ \\
\hline & Enzymmix F+Enzyme Blend & $42.74 \mathrm{~ns}$ & $945.05 \mathrm{~ns}$ & $1287.08 \mathrm{~ns}$ & $1.42 \mathrm{~ns}$ & $4.44 \mathrm{~ns}$ \\
\hline \multirow{6}{*}{ Nutritional level (N) } & Regular & $43.27 \mathrm{~ns}$ & $956.17 \mathrm{~ns}$ & $1268.80 \mathrm{~b}$ & $1.39 \mathrm{~b}$ & $2.77 \mathrm{~ns}$ \\
\hline & Reduced & $42.22 \mathrm{~ns}$ & $934.73 \mathrm{~ns}$ & $1321.43 \mathrm{a}$ & $1.48 \mathrm{a}$ & $3.52 \mathrm{~ns}$ \\
\hline & $\mathrm{CV}(\%)$ & 4,63 & 4.40 & 5.23 & 3.47 & $102.43 *$ \\
\hline & $P(E)$ & 0.3113 & 0.3049 & 0.7892 & 0.3120 & 0.5501 \\
\hline & $\mathrm{P}(\mathrm{N})$ & 0.1244 & 0.1342 & 0.0280 & $<0.0001$ & 0.7478 \\
\hline & $P(E \times N)$ & 0.9342 & 0.9345 & 0.9991 & 0.8905 & 0.7329 \\
\hline
\end{tabular}

Different lowercase letters in the column differ in each factor by Tukey's test at $5 \%$.

$\mathrm{ns}=$ not significant by Tukey's test at $5 \% ; \mathrm{CV}=$ coefficient of variation; DWG $=$ daily weight gain; FCR $=$ feed conversion ratio, * data transformed using Box-Cox.

Table 5 - Effect of the "enzyme" and "nutritional level" factors on performance variables in the period from 1 to 42 days of age

\begin{tabular}{|c|c|c|c|c|c|c|c|}
\hline \multirow{2}{*}{ Factor } & & \multicolumn{5}{|c|}{ Performance variable } & \multirow[b]{2}{*}{ PEI } \\
\hline & & DWG (g) & Weight (g) & Intake $(\mathrm{g})$ & FCR & Mortality (\%) & \\
\hline \multirow[t]{3}{*}{ Enzyme (E) } & Enzymmix F & $72.68 \mathrm{~ns}$ & $3100.53 \mathrm{~ns}$ & $5451.74 \mathrm{~ns}$ & $1.76 \mathrm{~ns}$ & $4.44 \mathrm{~ns}$ & $400.41 \mathrm{~ns}$ \\
\hline & $\begin{array}{l}\text { Enzyme Blend } \\
\text { Enzymmix F + }\end{array}$ & $72.59 \mathrm{~ns}$ & $3096.56 \mathrm{~ns}$ & $5394.94 \mathrm{~ns}$ & $1.75 \mathrm{~ns}$ & $4.72 \mathrm{~ns}$ & $401.54 \mathrm{~ns}$ \\
\hline & Enzyme Blend & $74.31 \mathrm{~ns}$ & $3168.57 \mathrm{~ns}$ & $5593.62 \mathrm{~ns}$ & $1.75 \mathrm{~ns}$ & $8.06 \mathrm{~ns}$ & $396.60 \mathrm{~ns}$ \\
\hline \multirow[t]{2}{*}{ Nutritional level (N) } & Regular & $73.58 \mathrm{~ns}$ & $3137.68 \mathrm{~ns}$ & $5433.87 \mathrm{~b}$ & $1.73 \mathrm{~b}$ & $5.37 \mathrm{~ns}$ & $409.63 \mathrm{a}$ \\
\hline & Reduced & $72.81 \mathrm{~ns}$ & $3106.10 \mathrm{~ns}$ & $5526.33 \mathrm{a}$ & $1.78 \mathrm{a}$ & $6.11 \mathrm{~ns}$ & $389.41 \mathrm{~b}$ \\
\hline \multicolumn{2}{|c|}{ CV $(\%)$} & 2.75 & 2.71 & 3.59 & 1.73 & 95.61 & 5.93 \\
\hline \multicolumn{2}{|c|}{$P(E)$} & 0.0814 & 0.0833 & 0.0557 & 0.5728 & 0.2202 & 0.8673 \\
\hline \multicolumn{2}{|c|}{$\mathrm{P}(\mathrm{N})$} & 0.2650 & 0.2729 & 0.1705 & $<0.0001$ & 0.6888 & 0.0168 \\
\hline \multicolumn{2}{|c|}{$P(E \times N)$} & 0.6312 & 0.6310 & 0.9458 & 0.3949 & 0.9310 & 0.4875 \\
\hline
\end{tabular}

Different lowercase letters in the column differ in each factor by Tukey's test at $5 \%$.

$\mathrm{ns}=$ not significant by Tukey's test at $5 \% ; \mathrm{CV}=$ coefficient of variation; $\mathrm{DWG}=$ daily weight gain; $\mathrm{FCR}=$ feed conversion ratio, $\mathrm{PEI}$ $=$ production efficiency index. 
the dietary nutritional levels led to lower performance $(p \leq 0.05)$ compared with the use of regular levels. This lower performance is characterized by the higher feed intake and worse feed conversion observed in both periods (Tables 4 and 5). Moreover, at the end of the experimental period, a lower $(\mathrm{p} \leq 0.05)$ production efficiency index was recorded for this treatment (Table 5). There was no interaction effect between enzyme and nutritional level of the diet on the evaluated performance parameters.

The lack of differences in the periods of 1 to 21 and 1 to 42 days of age of the birds indicates that the product tested here (Enzymmix F) has similar efficiency to that of the Brazilian product. At the same time, it also reveals a lack of synergism between the studied enzyme complexes, which, as previously mentioned, have distinct origins and enzymes. Dalólio et al. (2016) also did not find significant differences in bird performance using an enzyme complex at different concentrations. Those authors suggest that by adopting additional supply, an inclusion method used for Enzyme Blend, differences can be reduced, consequently reducing the likelihood of significant differences. Other authors, however, observed an improvement $(\mathrm{p} \leq 0.05)$ in the feed conversion of broilers fed corn and soybean mealbased diets supplemented with an enzyme complex under the same inclusion method (Pucci et al., 2010).

The nutritional reduction of the diets was not offset by the effect of the enzyme complexes under study. This result corroborates other authors who reported effects of diet density on broiler performance despite enzyme supplementation (Bonato et al. 2004). In practical terms, this result demonstrates that for the products tested here to be used without performance losses, these levels should be reduced to no more than 100 $\mathrm{Kcal} \mathrm{ME} / \mathrm{kg}$ apparent ME, 3\% limiting AA, and 2 units of crude protein.

There was no statistical difference for the yields of carcass and cuts as a function of the use of enzymes. However, a more in-depth analysis of the data revealed that the wing was lighter in the treatment containing the Enzyme Blend (Table 6). It should be noted that although there is a higher demand for this cut, the processing industry tends to value mostly the "breast" cut because of its added value. This cut, in turn, did not differ statistically across the treatments, but in absolute terms the breast weight was higher in the treatment using Enzymmix F (Table 6).
For most of the quantified variables, the enzyme complexes were efficient to the point that no significant difference was observed between the nutritional levels of the diets; once again, the exception was the wing weight (Table 6). Variations in the yield of this cut are commonly attributed to sex and line (Hellmeister Filho, 2003), which are factors that did not vary across the treatments, in this study.

Our data corroborate those reported by other authors who also did not find differences in the yields of carcass and primal cuts (breast, drumstick, and thigh) as affected by the use of enzyme complexes (Torres et al., 2003; Carvalho et al., 2009). The use of the same ingredient base (corn and soybean) for the formulation of the diet as well as the same line of the birds likely contributed to this result. Differences in yields of carcass and cuts are more common when different raw materials (Geron et al., 2015; Frank et al., 2016), lines (Api et al., 2017; Silva et al., 2017) and diet physical forms (Oliveira et al., 2011) are used.

With respect to the intestinal-quality data, there was a statistical difference for villus height in the jejunum, the most important segment for nutrient absorption (Uni, 2004). In this segment, an interaction effect between the studied factors was also observed on crypt depth (Table 7).

The Enzymmix $F$ treatment provided a greater villus height than the Enzyme Blend and Enzymmix F + Enzyme Blend treatments (Table 7), suggesting a positive effect of the use of Enzymmix F on this parameter, although such benefit did not lead to improved production performance at the end of the experimental period (Table 5). This greater villus height is believed to be associated with the use of Eisenia foetida as raw material, an organism known to produce meals with high levels of glutamic acid (Ignacio, 1993), which, as stated by Solta (2009), increases the height and weight of villi in the duodenum and jejunum of broilers.

The decomposition of the interaction $(\mathrm{p} \leq 0.05)$ between the "enzyme" and "nutritional level" factors shows that the use of the diet with nutritional levels reduced by 2 units of crude protein, $3 \%$ amino acids, and $100 \mathrm{kcal}$ energy led to a lower crypt depth in the treatment including the Enzyme Blend (Table 8). The balance between cell renewal and cell loss enables the maintenance of the villus size and the crypt depth (Mariorka et al., 2002). Thus, because a greater villus 
Table 6 - Effect of the "enzyme" and "nutritional level" factors on characteristics of carcass and cuts (drumstick + thigh, breast, and wings)

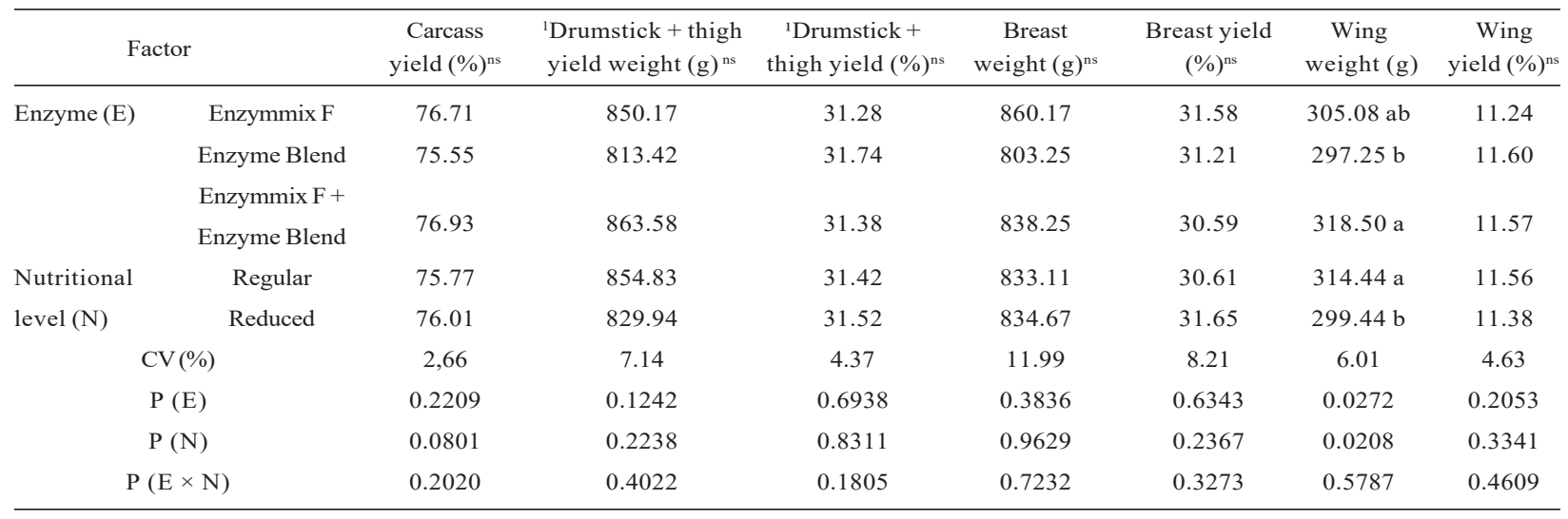

ns $=$ not significant by Tukey's test at $5 \% ; \mathrm{CV}=$ coefficient of variation.

$1=$ in the individual evaluation of the cut (drumstick and thigh), no statistical difference was observed, either.

Table 7 - Effect of the "enzyme" and "nutritional level" factors on the intestinal quality of the duodenum, jejunum, and ileum segments

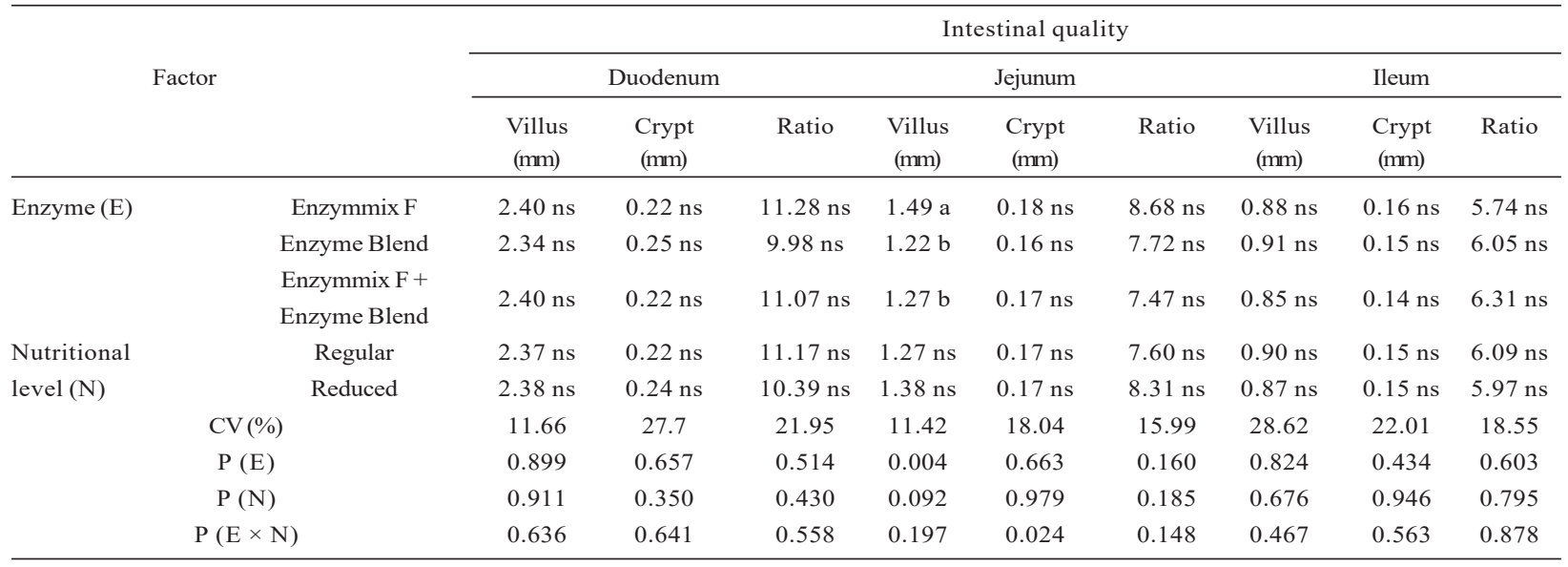

ns $=$ not significant by Tukey's test at $5 \% ; \mathrm{CV}=$ coefficient of variation.

Table 8 - Decomposition of the interaction between the "enzyme" and "nutritional level" factors on crypt depth in the jejunum segment

\begin{tabular}{lcc}
\hline \multirow{2}{*}{ Enzyme } & \multicolumn{2}{c}{ Nutritional level } \\
\cline { 2 - 3 } & Regular & Reduced \\
\hline Enzymmix F & $0.17 \mathrm{aA}$ & $0.18 \mathrm{aA}$ \\
Enzyme Blend & $0.19 \mathrm{aA}$ & $0.14 \mathrm{aB}$ \\
Enzymmix F + Enzyme Blend & $0.15 \mathrm{aA}$ & $0.19 \mathrm{aA}$ \\
\hline
\end{tabular}

Different lowercase letters in the column differ Tukey's test at $5 \%$. Different uppercase letters differ in the row by Tukey's test at 5\%. height was found in the treatment with Enzymmix F without an increase in crypt depth (Table 7), it is understood that the product has the potential to improve intestinal quality. However, Silva et al. (2011) submitted that the villus/crypt ratio is the best indicator of the digestive capacity of the small intestine, and this parameter did not differ across the treatments tested in the present study.

The decomposition of the interaction showed that crypt depth was higher in the treatment with Enzyme 
Blend and the regular nutritional level of the diet (Table 8). According to Jayaraman et al. (2013), deeper crypts are a result of augmented proliferative activity, which, in this study, may indicate a greater need for restoration of the villi, since their height did not differ according to the nutritional levels of the diet.

\section{CONCLUSION}

Compared to the Brazilian enzyme complex, the use of Enzymmix F increased wing weight and the height of the villi in the jejunum, demonstrating the potential of this product to improve the intestinal integrity of broilers.

Reducing the nutritional level of the feed resulted in worse feed conversion, warranting further studies to determine a possible reduction without any loss in performance.

\section{REFERENCES}

API, I.; TAKAHASHI, S.E.; MENDES, A.S. et al. Efeito da sexagem e linhagens sobre o desempenho e rendimento de carcaça de frangos de corte. Ciência Animal Brasileira, v. 18, p.1-10, e-32691, 2017. In: http://www.scielo.br/pdf/cab/v18/1809-6891-cab18-e32691.pdf (accessed November 21, 2018).

BARBOSA, N.A.A.; BONATO, M.A.; SAKOMURA, N.K. et al. Digestibilidade ileal de frangos de corte alimentados com dietas suplementadas com enzimas exógenas.

Comunicata Scientiae, v.5, n.4, p.361-369, 2014.

BONATO, E.L.; ZANELLA, I.; SANTOS, R. et al. Uso de enzimas em dietas contendo níveis crescentes de farelo de arroz integral para frangos de corte. Ciência Rural, v.34, n.2, p.511-516, 2004.

CARVALHO, J.C.C.; BERTECHINI, A.G.; FASSANI, E.J. et al. Desempenho e características de carcaça de frangos de corte alimentados com dietas à base de milho e farelo de soja suplementadas com complexos enzimáticos. Revista Brasileira de Zootecnia, v.38, n.2, p.292-298, 2009.
DALÓLIO, F.S.; MOREIRA, J.; VAZ, D.P. et al. Enzimas exógenas em dietas para frangos de corte. Revista Brasileira de Saúde e Produção Animal, v.17, n.2, p.149-161, 2016.

FRANK, R.; NUNES, R.V.; SCHONE, R.A. et al. Desempenho e parâmetros intestinais de frangos Label Rouge recebendo silagem de grãos úmidos de milho. Revista Ciência Agronômica, v.47, n.4, p.761-769, 2016.

GERON, L.J.V.; COSTA, F.G.; MORAES, K.J.S. et al. Consumo, desempenho e rendimento de carcaça de frangos de corte alimentados com rações contendo raspa de mandioca residual desidratada. Boletim de Indústria Animal, v.72, n. 4, p.304-310, 2015.

HELLMEISTER FILHO P. Efeitos de fatores genéticos e do sistema de criação sobre o desempenho e o rendimento de carcaça de frangos tipo caipira. Tese (Doutorado em Agronomia). Piracicaba, SP: ESALQ, 2003. 77p.

HUMANE FARM ANIMAL CARE. CHICKENS, Herndon VA; 2009. In: http://certifiedhumane.org/ wp-content/uploads/pdfs/Std09.Chickens.2J.pdf (accessed November 21, 2018).

IGNACIO, A.; CARLOS, A.; LUOIS, A. et al. Nutritional and toxicological evaluation of earthworm (Eisenia foetida) meal as a protein source for animal feed. Animal Feed Science and Technology, v.42, p.165-172, 1993.

JAYARAMAN, S.; THANGAVEL, G.; KURIAN, H. et al. Bacillus subtilis PB6 improves intestinal health of broiler chickens challenged with Clostridium perfringes - induced necrotic enteritis. Poultry Science, v.92, n.2, p.370-374, 2013.

MAIORKA, A.; BOLELI, I.C.; MACARI, M. Desenvolvimento e reparo da mucosa intestinal. In: MACARI, M.; FURLAN, R.L.; GONZALES, E. (2 Ed.) Fisiologia aviária aplicada a frangos de corte. Jaboticabal: Funep/Unesp; 2002. p.113-124.

MAVROMICHALIS, I. Mixed or single enzymes for non-starch carbohydrates? 2012. In: http:// www.allaboutfeed.net/Feed-Additives/Articles/ 2012/11/Mixed-or-single-enzymes-for-non-starchcarbohydrates-1494289W/ (accessed November 21, 2018). 
MENEGHETti, C. Associação de enzimas em rações para frangos de corte. Tese (Doutorado em Zootecnia). Lavras, MG: UFLA, 2013.93p.

OLIVEIRA, A.A.; GOMES, A.V.C.; OLIVEIRA, G.R. et al. Desempenho e características da carcaça de frangos de corte alimentados com rações de diferentes formas físicas. Revista Brasileira de Zootecnia, v.40, n.11, p. 2450-2455, 2011.

PUCCI, L.E.A.; RODRIGUES, P.B.; BERTECHINI, A.G. et al. Forma física, suplementação enzimática e nível nutricional de rações para frangos de corte na fase inicial: desempenho e digestibilidade dos nutrientes. Revista Brasileira de Zootecnia, v.39, n. 6, p.1271-1279, 2010.

RAVINDRAN, V. Feed enzymes: The science, practice, and metabolic realities. Journal

Applied of Poultry Research, v.22, n.3, p.628-636, 2013

ROSTAGNO, H.S. Tabelas brasileiras para aves e suínos: composição de alimentos e exigências nutricionais. Viçosa: UFV / DZO; 2011. 252p.

SAKOMURA, N.K.; ROSTAGNO, H.S. Métodos de pesquisa em nutrição de monogástricos. Jaboticabal: FUNEP; 2007. $283 p$.

SILVA, M.A.; PESSOTTIL, B.M.S.; ZANINI, S.F. et al. Óleo essencial de aroeira-vermelha como aditivo na ração de frangos de corte. Ciência Rural, v.41, n.4, p.676-681, 2011.
SILVA, M.T.P.; VELOSO, R.C.; PIRES, A.V.et al. Desempenho e características de carcaça de três genótipos comerciais de frangos de corte alimentados com diferentes dietas. Arquivo Brasileiro de Medicina Veterinária e Zootecnia, v.69, n.5, p.13111318, 2017

SOLTAN, M.A. Influence of dietary glutamine supplementation on growth performance, small intestinal morphology, immune response and some blood parameters of broiler chickens.

International Journal of Poultry Science, v.8, n.1, p.60-68, 2009.

TORRES, D.M.; TEIXEIRA, A.S.; RODRIGUES, P.B. et al. Eficiência das enzimas amilase, protease e xilanase sobre o desempenho de frangos de corte. Ciência e Agrotecnologia, v.27, n.6. p.1401-1408, 2003.

UNI, Z.; FERKET, R.P. Methods for early nutrition and their potential. Poultry Science, v.60, n.1, p.101-111, 2004.

THORPE, J.; BEAL, J.D.; Vegetable protein meals and the effects of enzymes. IN: BEDFORD, M.R.; PARTRIDGE, G.G. (2 Ed) Enzymes in farm animal nutrition. Wallingford: CabiPublishing, 2001. p.125-144.

VARGAS, R.C.; GERALDO, A.; ROCHA, T.C. et al. Complexo multienzimático em dietas de poedeiras comerciais. Revista de Ciências

Agroveterinárias, v.16, n.1, p.61-69, 2017.

Recebido para publicação em 20/04/2018 e aprovado em 18/11/2018. 